\title{
Papers
}

\section{Systematic review of the incidence and consequences of uterine rupture in women with previous caesarean section}

Topic: $299 ; 68 ; 159$

Jeanne-Marie Guise, Marian S McDonagh, Patricia Osterweil, Peggy Nygren, Benjamin K S Chan, Mark Helfand

\begin{abstract}
Objective To evaluate the incidence and consequences of uterine rupture in women who have had a delivery by caesarean section.

Design Systematic review.

Data sources Medline, HealthSTAR, Cochrane Database of Systematic Reviews, Cochrane Controlled Trials Register, National Centre for Reviews and Dissemination, reference lists, and national experts. Studies in all languages were eligible if published in full. Review methods Methodological quality was evaluated for each study by using criteria from the United States Preventive Services Task Force and the National Health Service Centre for Reviews and Dissemination. Uterine rupture was categorised as asymptomatic or symptomatic.

Results We reviewed 568 full text articles to identify 71 potentially eligible studies, 21 of which were rated at least fair in quality. Compared with elective repeat caesarean delivery, trial of labour increased the risk of uterine rupture by 2.7 (95\% confidence interval 0.73 to 4.73 ) per 1000 cases. No maternal deaths were related to rupture. For women attempting vaginal delivery, the additional risk of perinatal death from rupture of a uterine scar was 1.4 (0 to 9.8$)$ per 10000 and the additional risk of hysterectomy was 3.4 ( 0 to 12.6) per 10000 . The rates of asymptomatic uterine rupture in trial of labour and elective repeat caesarean did not differ significantly.

Conclusions Although the literature on uterine rupture is imprecise and inconsistent, existing studies indicate that 370 (213 to 1370) elective caesarean deliveries would need to be performed to prevent one symptomatic uterine rupture.
\end{abstract}

\section{Introduction}

Since at least 1916, the time of Edward Cragin's famous statement, "Once a caesarean always a caesarean," the medical profession has been concerned about the risk of catastrophic uterine rupture for women whose previous deliveries were by caesarean section. In the past 20 years, trial of labour has been encouraged for women who have had a caesarean delivery. Recent studies reporting that mother and fetus may be at greater risk than previously thought, largely because of uterine rupture, ${ }^{2}{ }^{3}$ have stirred controversy about the safety of vaginal birth after caesarean section. ${ }^{4-6}$

We sought to determine the incidence and consequences of uterine rupture for women with a low transverse caesarean section scar or unclassified scar (for which the direction of incision on the uterus is uncertain). We also searched for evidence about the effect of expanding the criteria for eligibility and of medical induction, and augmentation on maternal and infant morbidity and mortality. This review derives from an evidence based report conducted for the US Agency for Healthcare Research and Quality. ${ }^{7}$

\section{Methods}

Searching

The primary investigator and a medical librarian searched both Medline and HealthSTAR (1980 to 2002), using "vaginal birth after cesarean/caesarean", "trial of labor/labour", "trial of scar", "labor/labour", "delivery", "vaginal birth", "vaginal delivery", "cesarean/caesarean", "home childbirth", "natural childbirth", "obstetrical extraction", and "uterine rupture" as search terms. We searched the Cochrane Database of Systematic Reviews, Cochrane Controlled Trials Register, the Database of Abstracts of Reviews of Effectiveness, reference lists of pertinent studies, reviews, and expert recommendations. The search was limited to 1980 or later, as in 1980 a National Institutes of Health consensus conference established vaginal birth after caesarean as an acceptable choice. ${ }^{8}$

\section{Selection}

We considered controlled trials, cohort studies, case-control studies, and case series with at least 10 cases. We sought studies comparing uterine rupture rates and sequelae in women with low transverse caesarean scar or unclassified scar who chose trial of labour or elective repeat caesarean delivery (ERCD), and if these were not available, non-comparative studies reporting uterine rupture rates and subsequent
Department of Obstetrics and Gynecology, Oregon Health \& Science University, UHN-50, 3181 SW Sam Jackson Park Road, Portland, OR 97239-3098, USA

Jeanne-Marie Guise assistant professor

Evidence-based Practice Center, Oregon Health \& Science University

Marian S

McDonagh assistant professor Patricia Osterweil research assistant Peggy Nygren senior research associate

Benjamin K S Chan senior research associate

Mark Helfand director

Correspondence to: J-M Guise guisej@ohsu.edu

BMJ 2004;329:1-7 
morbidity or mortality. A study was considered relevant if it was in full manuscript form, included women with low transverse caesarean or unclassified scar, provided data regarding uterine rupture, and had been conducted in a developed country. We excluded studies focusing on particular medical or obstetric conditions (for example, gestational diabetes or pre-eclampsia). Non-English articles with English abstracts were included if they provided information not found in English-language literature.

Two investigators independently reviewed random titles and abstracts to establish reliable, reproducible inclusion criteria. Once reliability was established ( $\kappa$ of $\geq 0.80$ ), the primary investigator reviewed the remaining titles and abstracts.

\section{Validity assessment}

Two investigators independently rated the quality of the study, using criteria from the US Preventive Services Task Force and the NHS Centre for Reviews and Dissemination. ${ }^{9}{ }^{10}$ Studies received a poor rating if the groups assembled were not comparable (for example, elective repeat caesarean patients were not eligible for trial of labour); if classification of uterine rupture was unreliable or invalid, or classification was not applied equally among groups; if key confounders, such as number of caesarean deliveries or direction of prior caesarean (vertical or transverse) were given little or no attention; if there was differential attrition or, for randomised control trials, if intention to treat analysis was lacking.

All studies needed to define uterine rupture, or to provide enough information about rupture events to allow for classification and determination of likely association to prior caesarean section. We excluded studies that had used ICD-9 codes to identify uterine rupture because ICD-9 codes are inaccurate: in one study, only $480(39.8 \%)$ of 1244 suspected ruptures

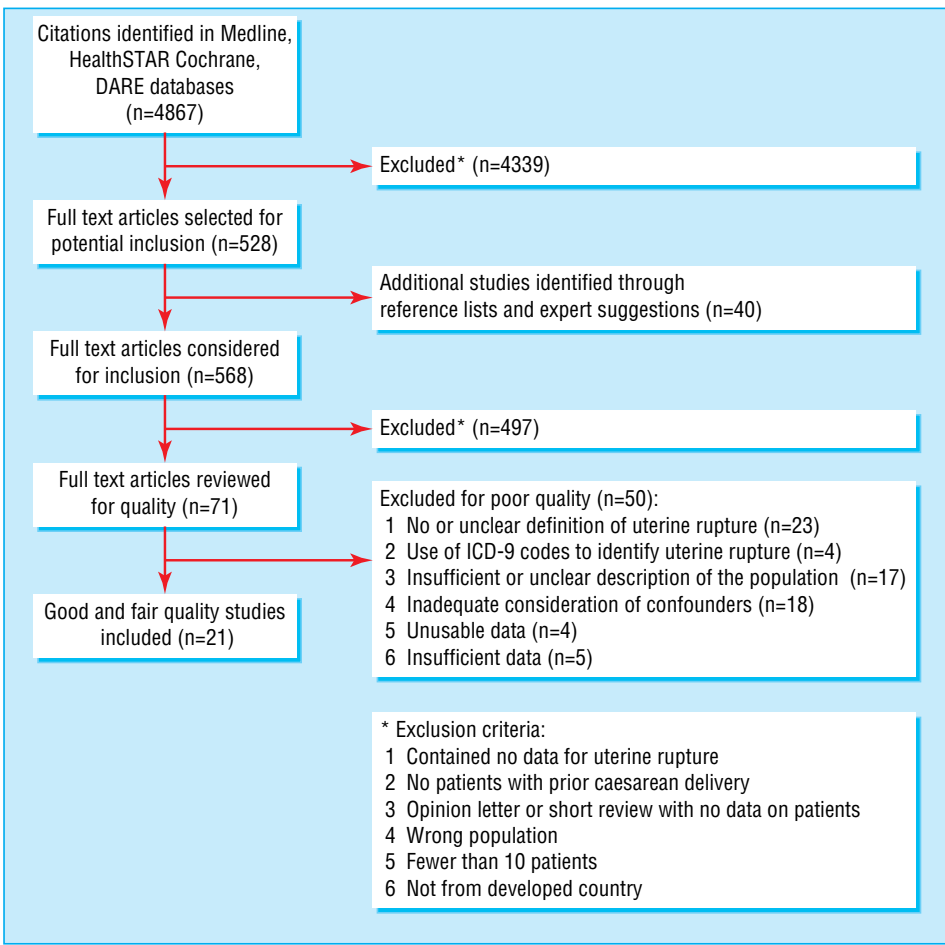

Fig 1 Eligibility of studies for inclusion in systematic review identified from ICD-9 codes were confirmed as true ruptures after records were reviewed. ${ }^{11}$

\section{Data abstraction and study characteristics}

From each study, two reviewers independently abstracted study design and setting; patients' characteristics; definition, rates, and predictors of uterine rupture; maternal and fetal outcomes; and methods of assessing or adjusting for confounders. When reviewers disagreed, agreement was reached by consensus. ${ }^{7}$

Terminology for rupture was inconsistent among studies, yet was crucial for understanding the incidence and consequences of the condition. We used "symptomatic uterine rupture" when uterine separation was diagnosed at laparotomy performed for maternal or fetal signs or symptoms associated with uterine rupture, such as fetal heart rate disturbances or maternal bleeding, and "asymptomatic uterine rupture" for uterine separation without signs or symptoms.

\section{Quantitative data synthesis}

We conducted several meta-analyses to estimate the risks associated with trial of labour and clinical factors that influence risk. Our primary outcomes of interest were the additional absolute risks of symptomatic uterine rupture, and of maternal or perinatal death, or hysterectomy, related to rupture, when trial of labour rather than repeat caesarean delivery was chosen. We were also interested in risks associated with management techniques such as induction or augmentation of labour, as well as signs or symptoms predicting poor outcomes from uterine rupture. Absolute risk differences and rates were calculated and pooled by random effects and fixed effects models, which weighted studies by the inverse of their variances, giving more weight to precise studies. To reduce bias, we included only studies of fair to good quality. Two investigators independently rated the quality of the study, using criteria from the US Preventive Services Task Force and the NHS Centre for Reviews and Dissemination. ${ }^{9}{ }^{10}$ Studies received a poor rating if the groups assembled were not comparable (for example, elective repeat caesarean patients were not eligible for trial of labour); if classification of uterine rupture was unreliable or invalid, or classification was not applied equally among groups; if key confounders, such as number of caesarean deliveries or direction of prior caesarean (vertical or transverse) were given little or no attention; if there was differential attrition or, for randomised control trials, if intention to treat analysis was lacking. A study received a fair rating if generally comparable groups were assembled but some question remained whether minor differences occurred in follow up; if measurement of uterine rupture was acceptable (for example, no definition but study details allowed for classification) and generally applied equally; if some, but not all, potential confounders were accounted for; and for randomised controlled trials, if intention to treat analysis was performed. As results from fixed effects and random effects models did not differ, we present the results from the random effects models.

\section{Results}

We identified 4867 citations, reviewed 568 full text articles, and identified 21 studies of fair to good quality (fig 1). We excluded 497 studies because they did not 
Table 1 Quality of study, definitions used, and predictors of uterine rupture

\begin{tabular}{|c|c|c|c|}
\hline Study, location & Quality & Terms and definitions & $\begin{array}{c}\text { Potential predictors of uterine rupture reported (No with predictor/total } \\
\text { cases of uterine rupture) }\end{array}$ \\
\hline $\begin{array}{l}\text { McMahon } 1996,{ }^{2} \\
\text { Canada }\end{array}$ & Good & $\begin{array}{l}\text { Uterine rupture: symptomatic defect of entire uterine wall requiring } \\
\text { operative intervention }\end{array}$ & Not reported \\
\hline $\begin{array}{l}\text { Smith } 2002,{ }^{12} \\
\text { Scotland }\end{array}$ & Fair & Uterine rupture: not reported & Not applicable \\
\hline Duff $1988,{ }^{14}$ USA & Good & $\begin{array}{l}\text { Uterine scar dehiscence: disruption of any portion of lower segment } \\
\text { incision (used to describe a patient with vaginal bleeding and fetal } \\
\text { bradycardia who delivered by repeat CD; Apgars } 4,8 ; 60 \% \text { of scar } \\
\text { disrupted) }\end{array}$ & $1 / 1$ vaginal bleeding and fetal bradycardia \\
\hline Flamm $1988,{ }^{15}$ USA & Fair & $\begin{array}{l}\text { Asymptomatic uterine window: small defects visualised at CD or palpated } \\
\text { at VD }\end{array}$ & $\begin{array}{l}\text { No sign: } 1 / 3 \mathrm{CD} \text { for failure to progress } \\
\text { Fetal distress: } 1 / 3 \\
\text { Abdominal pain: } 1 / 3\end{array}$ \\
\hline \multirow[t]{2}{*}{ Cowan $1994,{ }^{13}$ USA } & \multirow[t]{2}{*}{ Fair } & $\begin{array}{l}\text { Bloodless uterine scar dehiscence: any defect in the pre-existing caesarean } \\
\text { scar with no maternal or fetal compromise }\end{array}$ & \multirow{2}{*}{$\begin{array}{l}\text { Abnormal fetal tracing (immediate and prolonged fetal bradycardia): } 5 / 5 \\
\text { Oxytocin: } 3 / 5 \text { UR ( } 1 \text { vertical, } 1-2 \text { prior CD) } \\
\text { Epidural: } 1 / 5 \text { UR }\end{array}$} \\
\hline & & $\begin{array}{l}\text { True uterine rupture: Scott's definition - "a complete separation of the } \\
\text { wall of the pregnant uterus, with or without expulsion of the fetus, } \\
\text { endangering the life of the mother or fetus" (one rupture occurred at } \\
\text { fundus with an intact uterine scar) }\end{array}$ & \\
\hline Flamm $1994,{ }^{16}$ USA & Fair & $\begin{array}{l}\text { Uterine rupture: any defect that involved the entire uterine wall or was } \\
\text { symptomatic or required operative intervention }\end{array}$ & Not reported \\
\hline Flamm $1990,{ }^{17}$ USA & Fair & $\begin{array}{l}\text { Uterine rupture: any defect that involved the entire uterine wall or was } \\
\text { symptomatic or required operative intervention. (2/10 UR occurred after VD) }\end{array}$ & $\begin{array}{l}\text { Abnormal EFM: } 7 / 10 \text { "variable or prolonged bradycardia most common } \\
\text { warning sign" } \\
\text { Oxytocin: } 6 / 10 \text { UR; NS } v \text { non-rupture }\end{array}$ \\
\hline \multirow[t]{2}{*}{ Martin $1983,{ }^{18}$ USA } & \multirow[t]{2}{*}{ Fair } & $\begin{array}{l}\text { Dehiscence: non-traumatic separation of the uterine scar without bleeding } \\
\text { or extrusion of fetus into wound }\end{array}$ & \multirow[t]{2}{*}{ Not reported } \\
\hline & & $\begin{array}{l}\text { Uterine rupture: scar separation with bleeding, haematoma formation, or } \\
\text { extrusion of the fetus }\end{array}$ & \\
\hline \multirow[t]{2}{*}{$\begin{array}{l}\text { Meehan } 1989,{ }^{19} \\
\text { Ireland }\end{array}$} & \multirow[t]{2}{*}{ Fair } & $\begin{array}{l}\text { Bloodless dehiscence: dehiscence of uterine scar not associated with } \\
\text { bleeding; it includes small "window" defects and larger defects in which } \\
\text { bleeding was not a feature }\end{array}$ & \multirow[t]{2}{*}{$\begin{array}{l}\text { Fetal distress: } 1 / 1 \text { UR } \\
\text { Oxytocin: NS } \\
\text { Epidural: NS }\end{array}$} \\
\hline & & $\begin{array}{l}\text { True rupture: rupture of the uterine scar accompanied by intra-abdominal } \\
\text { or vaginal bleeding }\end{array}$ & \\
\hline Meier $1982,{ }^{20}$ USA & Fair & $\begin{array}{l}\text { Scar dehiscence: uterine scar separation (incidentally noted at caesarean } \\
\text { delivery) }\end{array}$ & No sign reported: $2 / 2$ dehiscences found at $C D$ \\
\hline Paul $1985,{ }^{21}$ USA & Fair & $\begin{array}{l}\text { Uterine dehiscence: any palpable and/or visualised uterine defect (further } \\
\text { subgrouped into dehiscences that required no intervention and those that } \\
\text { did require intervention, which were termed uterine rupture) }\end{array}$ & $\begin{array}{l}\text { Abdominal pain: } 2 / 5 \mathrm{UR} \\
\text { Postpartum bleeding: } 1 / 5 \mathrm{UR} \\
\text { No sign reported: arrest of dilation found UR } \\
\text { Partial extrusion of fetus: } 1 / 5 \text { UR } \\
\text { Abnormal fetal tracing: } 1 / 5 \mathrm{UR} \\
\text { Note: } 25 \mathrm{CD} \text { for "fetal distress" (18/751 TOL v } 7 / 458 \text { repeat CD ) (7/18 } \\
\text { TOL emergent CD, } 2 / 7 \text { ERCD emergent CD) }\end{array}$ \\
\hline Phelan $1987,{ }^{22}$ USA & Fair & Uterine dehiscence: scar separation not requiring operative intervention & $\begin{array}{l}\text { Fetal distress such as severe variable decelerations or prolonged fetal } \\
\text { bradycardia most frequent sign, no cases of UR with maternal pain and } \\
\text { changes in uterine tone }\end{array}$ \\
\hline \multirow[t]{3}{*}{ Stovall $1987,{ }^{23}$ USA } & \multirow[t]{3}{*}{ Fair } & Dehiscence: palpable or visualised defect in previous uterine scar & \multirow{3}{*}{$\begin{array}{l}\text { Pain, vaginal bleeding, loss of uterine tone in the one case of UR, NR } \\
\text { difference between UR and non-UR }\end{array}$} \\
\hline & & $\begin{array}{l}\text { Uterine window: dehiscence not requiring surgical intervention or blood } \\
\text { component replacement }\end{array}$ & \\
\hline & & Uterine rupture: dehiscence requiring intervention & \\
\hline $\begin{array}{l}\text { Connolly } 2001,{ }^{28} \\
\text { Ireland }\end{array}$ & Fair & $\begin{array}{l}\text { Scar dehiscence (further classified as partial and complete): not reported. } \\
\text { (Life threatening complication, "common symptoms include fetal distress, } \\
\text { abdominal pain, scar tenderness, vaginal bleeding; rarely massive } \\
\text { hemorrhage and hypovolemic shock may be presenting symptom") }\end{array}$ & 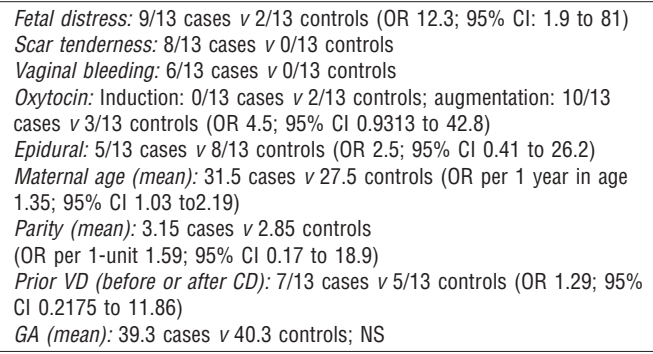 \\
\hline Leung $1993,{ }^{29}$ USA & Fair & $\begin{array}{l}\text { Uterine rupture: uterine scar separation and emergent laparotomy, acute } \\
\text { fetal distress necessitating operative intervention, or acute maternal } \\
\text { bleeding manifested by hypotension or shock }\end{array}$ & 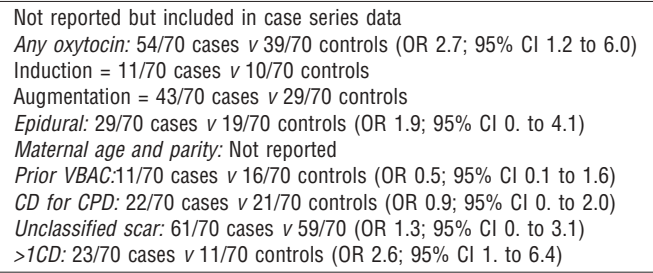 \\
\hline Bujold $2002,{ }^{31}$ Canada & Fair & $\begin{array}{l}\text { Complete uterine rupture: "uterine scar separation with the overlying } \\
\text { visceral peritoneum (uterine serosa) opened; all uterine ruptures had been } \\
\text { confirmed at the time of emergency laparotomy; records with uterine } \\
\text { dehiscences (not defined) were excluded" }\end{array}$ & $\begin{array}{l}\text { Fetal tracing abnormality: } 20 / 23 \text { patients } \\
\text { Abdominal pain: } 1 / 23 \text { first symptom ( } 3 \text { with abnormal tracings also } \\
\text { reported pain) } \\
\text { Vaginal bleeding: ( } 1 \text { of the patients with abnormal fetal tracing) } \\
\text { Haematuria: } 2 / 23 \text { first sign } \\
\text { Oxytocin: } 5 / 9 \text { metabolic acidosis } v 9 / 14 \text { without acidosis; NS } \\
\text { Induction of labour: } 3 / 9 \text { with acidosis } v 5 / 14 \text { without; NS } \\
\text { Epidural: } 8 / 9 \text { with acidosis } v 12 / 14 \text { without acidosis; NS }\end{array}$ \\
\hline
\end{tabular}


Table 1 Quality of study, definitions used, and predictors of uterine rupture (continued)

\begin{tabular}{|c|c|c|c|}
\hline Study, location & Quality & Terms and definitions & $\begin{array}{l}\text { Potential predictors of uterine rupture reported (No with predictor/total } \\
\text { cases of uterine rupture) }\end{array}$ \\
\hline Leung $1993,{ }^{30}$ USA & Fair & $\begin{array}{l}\text { Uterine rupture: uterine scar separation and emergent laparotomy, acute } \\
\text { fetal distress necessitating operative intervention, or acute maternal } \\
\text { bleeding manifested by hypotension or shock }\end{array}$ & $\begin{array}{l}\text { Fetal tracing abnormality: } 91 / 99 \\
\text { Pain: } 13 / 99 \\
\text { Vaginal bleeding: } 11 / 99 \\
\text { Oxytocin: NS in extrusion } \\
\text { Epidural: NS in extrusion } \\
\text { Maternal age: NS for extrusion } \\
\text { Parity: NS for extrusion } \\
\text { Prior VBAC: } 16 \text { patients with prior VBAC had rupture } \\
\text { CD for CPD: NS }\end{array}$ \\
\hline
\end{tabular}

$\mathrm{CD}=$ caesarean delivery; $\mathrm{Cl}=$ confidence interval; $\mathrm{CPD}=$ cephalopelvic disproportion; $\mathrm{EFM}=$ electrofetal monitor; $\mathrm{ERCD}=$ elective repeat caesarean delivery; $\mathrm{GA}=$ gestational age; NS=no significant difference; $\mathrm{OR}=0 \mathrm{dds}$ ratio; $\mathrm{UR}=$ uterine rupture; $\mathrm{VBAC}=\mathrm{vaginal}$ birth after caesarean ; $\mathrm{VD}=$ vaginal delivery.

meet inclusion criteria. No articles written in languages other than English met the inclusion criteria. Of the 71 studies considered potentially eligible, 50 received a poor rating ( 16 for two or more reasons).

\section{Study characteristics}

The included studies consisted of two large, population based retrospective studies, ${ }^{2}{ }^{12} 15$ prospective cohort studies, ${ }^{13-27}$ two case-control studies, ${ }^{28}{ }^{29}$ and two case series $^{30}{ }^{31}$ (table 1). Cohort studies defined the trial of labour group as women who had had a caesarean delivery (sometimes including women with scar of unclassified origin or low vertical scar) who had a trial of labour ending in vaginal or caesarean delivery. Often the repeat caesarean group was defined as women without a trial of labour (sometimes including women for whom caesarean section was indicated). Terms describing severity of rupture were used inconsistently; the term "dehiscence" usually signified incidental findings of a scar defect at caesarean or uterine exploration after vaginal delivery, but in three studies $^{142128}$ it also included symptomatic ruptures. Thirteen studies used the terms "complete uterine rupture" or "true uterine rupture," 1213 15-19 22 23 29-31 but these gave inconsistent definitions: separation requiring operative intervention (for example, emergent caesarean for maternal bleeding or fetal heart rate abnormality with scar separation); extrusion of fetus at caesarean for failure to progress; scar with bleeding, haematoma formation, or extrusion of fetus; or exclusively for separations with serious maternal or infant consequences (hysterectomy or death).

\section{Data synthesis}

Symptomatic uterine rupture

Ten of 11 observational studies provided the best evidence on the occurrence of symptomatic rupture (table 2). ${ }^{2} 13-18202223$ Symptomatic rupture rates in prospective cohort studies ranged from $0 / 1000$ in a small study ${ }^{20}$ to $7.8 / 1000$ in the largest,${ }^{16}$ with a pooled

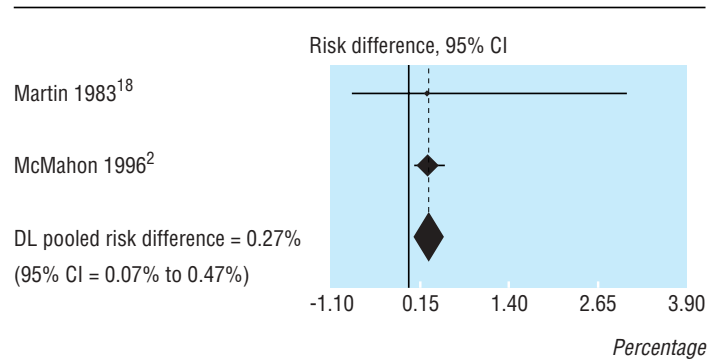

Fig 2 Symptomatic uterine rupture: trial of labour versus elective repeat caesarean delivery rate of $3.8(95 \%$ confidence interval 1.3 to 6.2$)$ per 1000 trials of labour. Only one retrospective and one prospective study provided comparative data for symptomatic rupture in trial of labour versus elective repeat caesarean (fig 2). ${ }^{218}$ When combined, these data show an additional risk of 2.7 (0.73 to 4.73) symptomatic ruptures per 1000 .

Perinatal deaths-Classification and reporting inconsistencies make it difficult to assess the risk of perinatal death due to rupture. Six cohort studies ${ }^{14-16} 182023$ including from 162 to 5022 trials of labour reported no perinatal deaths related to rupture; three other cohort studies $\left(3957,{ }^{17} 3249,{ }^{2}\right.$ and 1796 trials of labour $^{22}$ ) reported rates of $14 \%(1 / 7), 20 \%(2 / 11)$, and $60 \%(3 / 5),{ }^{2} 1722$ and two case series reported rates of $6 \%$ and $4 \%{ }^{30}{ }^{31}$ Overall, six deaths were reported in 74 symptomatic ruptures, corresponding to an additional 1.4 (0 to 9.8) perinatal deaths per 10000 trials of labour. ${ }^{2} 13-18$ 20-23 3031 By contrast, an analysis of linked data from the Scottish Morbidity Record and Stillbirth and Neonatal Death Enquiry found 20 perinatal deaths among 15515 trials of labour compared to none among 9014 planned caesareans. ${ }^{12}$ Their rate of 12.9 (7.9 to 19.9 ) per 10000 is almost 10 times higher than our estimate. The death rate for trial of labour $(20$ perinatal deaths: 8 in vaginal deliveries and 12 in emergent caesarean deliveries) may be spuriously high -and that for repeat caesarean delivery spuriously low-because all emergent caesarean deliveries and vaginal deliveries were classified as trials of labour regardless of intended delivery route. In a separate study, two of nine (22\%) emergent caesareans were in women who requested repeat caesarean. ${ }^{21}$ If this proportion were applied to the Scottish study, three of the 12 emergent perinatal deaths would have occurred in the planned repeat caesarean group, and the difference would no longer be statistically significant.

Hysterectomy-In the five cohort studies reporting on hysterectomies related to rupture, seven hysterectomies occurred in 60 symptomatic ruptures (13\%; $4 \%$ to $27 \%) .^{214-17}$ These data indicate that 3.4 (0 to 12.6 ) per 10000 women choosing trial of labour sustain a rupture that would necessitate hysterectomy.

\section{Asymptomatic uterine rupture}

Eight prospective cohort studies reported performing uterine exploration after vaginal birth after a previous caesarean (table 2). ${ }^{14-18}{ }^{21-23}$ Five reported routinely performing manual uterine exploration after vaginal birth. ${ }^{1415} 1822{ }^{23}$ In these studies, rates of asymptomatic uterine rupture, or dehiscence, ranged from $5 / 1000$ to $20 / 1000,,^{20}{ }^{23}$ with a mean weighted average rate of 13 per 1000 trials of labour. In three comparative studies 


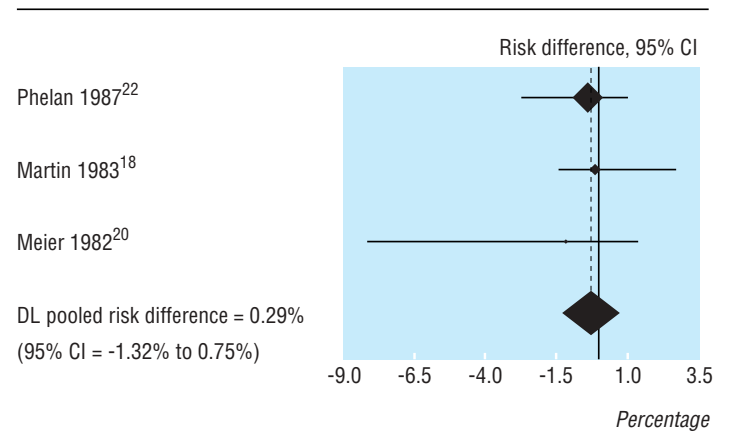

Fig 3 Asymptomatic uterine rupture: trial of labour versus elective repeat caesarean delivery

the rates for asymptomatic rupture in trial of labour and elective repeat caesarean were not significantly different (16 (5.4 to 28.4) per $1000 v 13$ (4.3 to 26.2) per 1000 ; fig 3$).{ }^{182022}$

\section{Increased incidence with induction}

Oxytocin use was associated with a twofold to fourfold increased risk of uterine rupture in two case-control studies. ${ }^{28}{ }^{29}$ This finding has not been confirmed in cohort studies or controlled trials. In prospective cohort studies, the use of oxytocin ${ }^{13}{ }^{21} 23-25$ or prostaglandin ${ }^{26}{ }^{27}$ was not associated with a higher risk of uterine rupture.
Predictors of major morbidity from rupture

Abnormalities in fetal heart rate were the most common sign of rupture, occurring in $55-87 \%$ of uterine rupture events. Other signs reported were vaginal bleeding, pain, and disturbances of uterine contractions.

No properly designed studies have directly evaluated whether fetal heart rate signs predict-or whether acting on them prevents-mortality and major morbidity related to uterine ruptures. Two case series that examined whether delays in delivery after fetal bradycardia were associated with infant morbidity had conflicting results. ${ }^{30}{ }^{31}$ Leung et al found that fetal heart rate disturbances occurred in 91/99 uterine ruptures $(92 \%)$, with 56 having prolonged deceleration only. ${ }^{30}$ No prolonged clinical morbidity (death, asphyxia, or intubation) occurred when delivery took place within 17 minutes of onset of deceleration, but four cases (1 asphyxia and 3 intubations) occurred in infants delivered after 17 minutes. The three neonates requiring intubation were extubated within 24 hours (range 1-24 hours) and were discharged from the hospital without adverse sequelae. If these three temporary neonatal intubations were excluded, one neonatal asphyxia and no deaths would remain. A more recent case series of 23 uterine ruptures included four cases of brain injury or death. The authors found no relation

Table 2 Results of studies comparing trial of labour and emergency repeat caesarean delivery

\begin{tabular}{|c|c|c|c|c|c|c|c|}
\hline \multirow[b]{2}{*}{ Study } & \multirow[b]{2}{*}{ Characteristics of population } & \multicolumn{2}{|c|}{ Sample size } & \multirow{2}{*}{$\begin{array}{c}\text { Uterine } \\
\text { exploration }\end{array}$} & \multicolumn{2}{|c|}{ No $(\%)$ of uterine ruptures } & \multirow[b]{2}{*}{ Reported associated major morbidity } \\
\hline & & TOL & ERCD & & Symptomatic & Asymptomatic & \\
\hline Cowan $1994^{13}$ & $\begin{array}{l}\text { All vertical scars excluded; } \\
\text { unclassified scars and more than } 1 \\
\text { previous caesarean allowed }\end{array}$ & 593 & & Not reported & TOL - $5(0.8)$ & Not reported & $\begin{array}{l}1 \text { fetus with severe neurological } \\
\text { sequelae }\end{array}$ \\
\hline Flamm $1994^{16}$ & $\begin{array}{l}\text { All vertical scars excluded; } \\
\text { unclassified scars allowed }\end{array}$ & 5022 & 2207 & Discretion & TOL - $39(0.8)$ & Not reported & $\begin{array}{l}0 \text { maternal and neonatal deaths, } 3 / 39 \\
\text { hysterectomies }\end{array}$ \\
\hline Duff $1988^{14}$ & $\begin{array}{l}\text { One prior LTCD and unclassified scar } \\
\text { not allowed }\end{array}$ & $227^{\star}$ & & Yes & TOL - $1(0.4)$ & Not reported & 0 maternal or perinatal deaths \\
\hline Flamm $1988^{15}$ & $\begin{array}{l}\text { LTCD, unclassified scar and more } \\
\text { than } 1 \text { previous caesarean allowed }\end{array}$ & $1776+$ & & Yes (discretion?) & TOL - $3(0.2)$ & TOL - $11(0.6)$ & $\begin{array}{l}\text { Symptomatic UR: TOL - } 0 \text { maternal } \\
\text { and neonatal deaths, } 1 \text { hysterectomy }\end{array}$ \\
\hline Flamm $1990^{17}$ & $\begin{array}{l}\text { LTCD, unclassified scars and more } \\
\text { than } 1 \text { previous caesarean allowed }\end{array}$ & 3957 & & $\begin{array}{l}\text { Majority no longer } \\
\text { did }\end{array}$ & TOL - $7(0.2)$ & Not reported & $\begin{array}{l}0 \text { maternal deaths; } 1 \text { hysterectomy } \\
\text { with infant born vaginally, Apgar 9; } 3 \\
\text { infants with Apgar }<7 \text { (one cerebral } \\
\text { palsy at } 15 \text { months); } 1 \text { perinatal } \\
\text { death related to rupture }\end{array}$ \\
\hline Phelan $1987^{22}$ & $\begin{array}{l}\text { Low vertical scars, unclassified scars, } \\
\text { LTCD during 2nd year and more than } \\
1 \text { previous caesarean allowed }\end{array}$ & 1796 & 314 & Yes & TOL - $5(0.3)$ & $\begin{array}{l}\text { TOL }-34(1.9) \\
\text { ERCD - } 7(2.2)\end{array}$ & $\begin{array}{l}\text { Symptomatic UR: TOL - } 1 \text { neonatal } \\
\text { death, post rupture, scar intact, fetal } \\
\text { bradycardia (sign), } 4600 \mathrm{~g} \mathrm{Apgar} \\
0,0,3 \text {; none in transverse scar }\end{array}$ \\
\hline Stoval $1987^{23}$ & $\begin{array}{l}\text { More than } 1 \text { LTCD or LVCD allowed; } \\
\text { not clear what was done with } \\
\text { unclassified scars }\end{array}$ & 272 & & Yes & TOL - $1(0.4)$ & TOL - 6 (2.2) & $\begin{array}{l}\text { Symptomatic UR: TOL - } 0 \text { maternal } \\
\text { or fetal deaths }\end{array}$ \\
\hline Paul $1985^{21}$ & $\begin{array}{l}\text { Not more than } 1 \text { previous caesarean } \\
\text { allowed; low vertical scars, } \\
\text { unclassified scars and LTCD allowed }\end{array}$ & 751 & 157 & Yes & TOL $-5(0.7) \ddagger$ & $\begin{array}{l}\text { TOL }-11(1.5) \ddagger \\
\text { ERCD }-4(2.5) \ddagger\end{array}$ & $\begin{array}{l}\text { Symptomatic UR: TOL- } 0 \text { maternal } \\
\text { deaths, } 2 \text { fetal deaths (classical } \\
\text { incision } 3 \text { prior } C D \text {, fundal incision), } \\
0 \text { hysterectomies }\end{array}$ \\
\hline Martin $1983^{18}$ & $\begin{array}{l}1 \text { or more LTCD or LVCD allowed, no } \\
\text { rupture occurred in the } 76 \text { with prior } \\
\text { vertical scars }\end{array}$ & 162 & 555 & Yes & $\begin{array}{l}\text { TOL }-1 \text { failed }(0.6) \\
\text { ERCD }-2(0.4)\end{array}$ & $\begin{array}{l}\text { TOL }-1 \text { successful, } 3 \\
\text { failed }(2.5) \\
\text { ERCD }-4(0.7)\end{array}$ & $\begin{array}{l}\text { Symptomatic UR: TOL - } 0 \text { maternal } \\
\text { or fetal deaths } \\
\text { ERCD - } 0 \text { maternal or perinatal } \\
\text { deaths, } 0 \text { hysterectomies }\end{array}$ \\
\hline Meier $1982^{20}$ & $\begin{array}{l}1 \text { or more LTCD allowed, no "obvious } \\
\text { CPD" allowed }\end{array}$ & 207 & 62 & Not reported & Not reported & $\begin{array}{c}\text { TOL - } 1 \text { (0.48) ERCD } \\
-1(1.6)\end{array}$ & $\begin{array}{l}\text { Symptomatic UR: TOL - } 0 \text { maternal } \\
\text { and fetal deaths }\end{array}$ \\
\hline McMahon $1996^{2}$ & $\begin{array}{l}1 \text { LTCD allowed; not clear what was } \\
\text { done with unclassified scars }\end{array}$ & 3249 & 2889 & Not reported & $\begin{array}{c}\text { TOL - } 10(0.3) \\
\text { ERCD - } 1(0.03)\end{array}$ & Not reported & $\begin{array}{l}\text { TOL - } 0 \text { maternal deaths, } 2 \text { perinatal } \\
\text { deaths, } 2 \text { hysterectomies; ERCD - } \\
0 \text { maternal or perinatal deaths, } \\
0 \text { hysterectomies }\end{array}$ \\
\hline
\end{tabular}

$\mathrm{CPD}=$ cephalopelvic disproportion; $E R C D=$ elective repeat caesarean delivery; $L T C D=l o w$ transverse caesarean delivery; $L V C D=l o w$ vertical caesarean delivery; $T O L=t$ trial of labour; $U R=u t e r i n e$ rupture.

${ }^{*}$ Called dehiscence but symptomatic.

tOne third still had thin layer of peritoneum over scar.

$\ddagger$ Included in Phelan $1987^{22}$ 
between outcome and interval between onset of fetal heart rate deceleration to delivery. ${ }^{31}$

\section{Discussion}

This report aimed to answer a question on the minds of patients, providers, and policy makers: what additional risks does a woman who has had a caesarean delivery assume if she chooses to attempt vaginal delivery rather than have a caesarean section? Most of the literature focuses on the risk of uterine rupture in the trial of labour group, with an implicit assumption that this risk would be eliminated by elective repeat caesarean delivery. If this assumption were true, it would take 263 elective repeat caesareans to prevent one uterine rupture due to trial of labour. However, elective repeat caesarean delivery is not guaranteed to prevent uterine rupture. In two comparative studies, trial of labour posed an additional risk of $0.27 \%(2.7 / 1000 ; 95 \%$ confidence interval 0.73 to 4.73$)^{2}{ }^{18}$; thus it would take 370 (213 to 1370 ) elective repeat caesareans to prevent one symptomatic uterine rupture due to trial of labour.

\section{Morbidity}

Patients are also concerned about additional morbidity. About 5\% of symptomatic uterine ruptures were associated with perinatal mortality and $13 \%$ with hysterectomy. This translates to 7142 elective repeat caesareans to prevent one rupture related perinatal death and 2941 to prevent one rupture related hysterectomy. It would take only one misclassified case of symptomatic uterine rupture in the smaller study and five in the largest ${ }^{2}$ to entirely negate the observed difference in symptomatic uterine rupture between groups. Caution must be used in interpreting these results.

Serious morbidity or mortality due to uterine rupture is rare, making it difficult to study. As a result, studies have focused on the occurrence of uterine rupture rather than how often bad outcomes result from it. The existing evidence is sufficient to conclude there is an increased risk of symptomatic uterine rupture for trial of labour over elective repeat caesarean and that caesarean delivery is not completely protective. However, most uterine ruptures do not have serious consequences, and patients and clinicians may wish to base decisions on the likelihood of significant morbidity or mortality for the mother and baby rather than on the occurrence of uterine rupture itself.

\section{Induction}

We found insufficient evidence to make a reliable estimate of the risk of uterine rupture when oxytocin or prostaglandins are used during labour. There is a temptation to make a conclusion on the use of prostaglandins to induce trials of labour, especially with the large effect reported by Lydon-Rochelle et al (relative risk of uterine rupture 15.6 ; 8.1 to 30$){ }^{3}$ We excluded this study because the use of ICD-9 codes to identify uterine rupture has been shown to be only about $40 \%$ accurate. ${ }^{11}$ If the Lydon-Rochelle study missed $60 \%$ of cases, we would still expect to find a significant increase in uterine rupture among women receiving prostaglandins: studies using better methods of identifying ruptures produce a relative risk of approximately 6. Prostaglandins did not increase the risk of uterine rupture in other observational studies.
Although the studies we reviewed were much smaller, overall the number of women receiving prostaglandins was similar in the largest cohort study included and the Lydon-Rochelle study. Whether prostaglandins really increase the risk is still open to question.

The relation between fetal heart rate disturbances and uterine rupture is unclear. Studies examining the relation between duration of fetal heart rate disturbance, particularly prolonged bradycardia and adverse perinatal outcomes, report conflicting results. Because the definition of uterine rupture often includes uterine ruptures that are discovered when a caesarean section is done because of fetal heart rate disturbances, it is impossible to determine the accuracy of fetal heart rate as a premonitory sign. Finding a uterine wall defect in this context does not necessarily signify that the defect was the cause of the fetal heart rate abnormality or that morbidity in the infant would be attributable directly to rupture.

\section{Methodological issues}

Existing studies do not permit a precise estimate of the frequency of serious events, which occur once in every 1000-10000 deliveries. A randomised trial of this question would have to be huge and might fail if women preferred to make their own decision rather than accept a random assignment to trial of labour or elective repeat caesarean. For an observational study, the major challenges are to accurately classify exposures (trial of labour, elective repeat caesarean, induction, and augmentation) and outcomes (rupture related events). Attempts have been made to classify a labour after delivery as a trial of labour or elective repeat caesarean, but these are fraught with bias. For example, women who intend to have a trial of labour but undergo early labour and decide on caesarean section are difficult to distinguish from women who "fail" trial of labour. Accounting for differences in the time of exposure is important, since women who choose elective repeat caesarean commonly deliver before 40 weeks whereas women choosing trial of labour may deliver up to 43 weeks.

Although degrees of measurement bias and misclassification are unavoidable, a multicentre prospective cohort study or national registry would offer the best opportunity to guide the design of effective preventive strategies. Meanwhile, this review indicates that there is less than a $1 \%$ chance that a woman with a low transverse caesarean scar or scar of unclassified origin will sustain a uterine rupture as a consequence of attempting vaginal delivery; that elective repeat caesarean does not always prevent uterine rupture; and that for more than two thirds of women who experience a uterine rupture, neither they nor their infant will have severe health consequences related to uterine rupture.

Contributors: J-MG and MSMcD contributed to the conception and design and analysis of data and drafting and revising of the article. PO contributed to the design and assembly of data, drafting and revising of the article, technical support. PN contributed to the design, revising of the article, and technical support. BKSC contributed to analysis of data, drafting and revising of the article, and statistical expertise. MH contributed to conception and design, interpretation of data, drafting and revising of the article. J-MG, MSMcD, PO, and MH approved the final version. J-MG is guarantor.

Funding: This study was conducted by the Oregon Health \& Science University Evidence-based Practice Center under 


\section{What is already known}

Perceptions of high risk for uterine rupture cause many patients and practitioners to avoid vaginal birth after caesarean delivery

Epidemiological studies show an association between previous caesarean section and uterine rupture

\section{What this study adds}

Symptoms of uterine rupture were more common in women undergoing trial of labour than planned repeat caesarean delivery, but the additional risk is less than previously thought

For every 10000 women attempting trial of labour there would be 27 additional symptomatic uterine ruptures, 1.4 perinatal deaths related to rupture, and 3.4 hysterectomies related to rupture

Studies need to use standard and precise definitions for uterine rupture and related outcomes

contract to the Agency for Healthcare Research and Quality, Rockville, MD (contract 290-97-0018, task order No 9). Support for J-MG was also provided by the Agency for Healthcare Research and Quality grant No 1 K08 HS11338-01.

Competing interests: None declared.

Ethical approval: Not required.

1 Cragin EB. Conservatism in obstetrics. $N$ Y Med J 1916;104:1-3.

2 McMahon MJ, Luther ER, Bowes WA, Olshan AF. Comparison of a trial of labor with an elective second cesarean section. $N$ Engl J Med of labor with an

3 Lydon-Rochelle M, Holt VL, Easterling TR, Martin DP. Risk of uterine rupture during labor among women with a prior cesarean delivery. N Engl J Med 2001;345:3-8.

Greene MF. Vaginal delivery after cesarean section-is the risk acceptable? [letter; comment]. N Engl J Med 2001;345:54-5.

5 Flamm BL. Once a cesarean, always a controversy. Obstet Gynecol 1997;90:312-5.

6 Scott JR. Putting elective cesarean into perspective [comment]. Obstet Gynecol 2002;99:967-8.

7 Guise J, McDonagh M, Hashima J, Kraemer D, Eden K, Berlin M, et al. Vaginal birth after cesarean (VBAC). Evidence report/technology assessment vaginal birth after cesarean (VBAC). Evidence report/technology assessment (prepared by the Oregon Health $\mathcal{E}$ Science University Evidence-based Practice
Center under contract N. 290-97-0018). Rockville, MD: Agency for Healthcare Research and Quality Publication, 2003.

8 Cesarean childbirth: report of a consensus development conference sponsored by the NICHHD in Conjunction with the National Center for
Health Care Technology and assisted by the Office for Medical Applications of Research. NIH Publication. 1981;82-2067.

9 Harris RP, Helfand M, Woolf SH, Lohr KN, Mulrow CD, Teutsch SM, et al. Current methods of the US Preventive Services Task Force: a review of the process. Am J Preventive Med 2001;20(suppl):21-35.

10 Khan K, Riet G, Popay J, Nixon J, Kleijnen J. Study quality assessment. Undertaking systematic reviews of research effectiveness: CRD's guidance for those carrying out or commissioning reviews. York: NHS Centre for Reviews and Dissemination, 2001.

11 Weiss J, Nannini A, Fogerty S, Sachs B. Use of hospital discharge data to monitor uterine rupture-Massachusetts, 1990-1997; US Department of Health \& Human Services. MMWR Morbid Mortal Wkly Rep 2000;49:245-8.

12 Smith GCS, Pell JP, Cameron AD, Dobbie R. Risk of perinatal death associated with labor after previous cesarean delivery in uncomplicated term pregnancies. JAMA 2002;287:2684-90.

13 Cowan RK, Kinch RA, Ellis B, Anderson R. Trial of labor following cesarean delivery. Obstet Gynecol 1994;83:933-6.

14 Duff P, Southmayd K, Read JA. Outcome of trial of labor in patients with a single previous low transverse cesarean section for dystocia. Obstet Gynecol 1988;71:380-4.

15 Flamm BL, Lim OW, Jones C, Fallon D, Newman LA, Mantis JK. Vaginal birth after cesarean section: results of a multicenter study. Am J Obstet Gynecol 1988;158:1079-84.

16 Flamm BL, Goings JR, Liu Y, Wolde-Tsadik G. Elective repeat cesarean delivery versus trial of labor: a prospective multicenter study. Obstet delivery versus trial of

17 Flamm BL, Newman LA, Thomas SJ, Fallon D, Yoshida MM. Vaginal birth after cesarean delivery: results of a 5 -year multicenter collaborative study. Obstet Gynecol 1990;76:750-4.

18 Martin JN, Harris BA, Huddleston JF, Morrison JC, Propst MG, Wiser $\mathrm{WL}$, et al. Vaginal delivery following previous cesarean birth. AmJ Obstet Gynecol 1983;146:255-63.

19 Meehan FP, Burke G. Trial of labour following prior section: a 5 year prospective study (1982-1987). Eur J Obstet, Gynecol Reprod Bio 1989;31: 109-17.

20 Meier PR, Porreco RP. Trial of labor following cesarean section: a two-year experience. Am J Obstet Gynecol 1982;144:671-8.

21 Paul RH, Phelan JP, Yeh SY. Trial of labor in the patient with a prior cesarean birth. Am J Obstet Gynecol 1985;151:297-304.

22 Phelan JP, Clark SL, Diaz F, Paul RH. Vaginal birth after cesarean. Am J Obstet Gynecol 1987;157:1510-5.

23 Stovall TG, Shaver DC, Solomon SK, Anderson GD. Trial of labor in previous cesarean section patients, excluding classical cesarean sections. Obstet Gynecol 1987;70:713-7.

24 Blanchette $\mathrm{H}$, Blanchette M, McCabe J, Vincent S. Is vaginal birth after cesarean safe? Experience at a community hospital. Am J Obstet Gynecol 2001;184:1478-87.

25 Flamm BL, Goings JR, Fuelberth NJ, Fischermann E, Jones C, Hersh E. Oxytocin during labor after previous cesarean section: results of a multiOxytocin during labor after previous cesare

26 Flamm BL, Anton D, Goings JR, Newman J. Prostaglandin E2 for cervical ripening: a multicenter study of patients with prior cesarean delivery. $A m$ J Perinatol 1997;14:157-60.

27 Blanco JD, Collins M, Willis D, Prien S. Prostaglandin E2 gel induction of patients with a prior low transverse cesarean section. Am J Perinatol 1992;9:80-3.

28 Connolly GA, Razak ARA, Conroy R, Harrison RFH, McKenna PF. A five year review of scar dehiscence in the Rotunda Hospital Dublin. Irish Med J 2001;94:176-8.

29 Leung AS, Farmer RM, Leung EK, Medearis AL, Paul RH. Risk factors associated with uterine rupture during trial of labor after cesarean delivery: a case-control study. Am J Obstet Gynecol 1993;168:1358-63.

30 Leung AS, Leung EK, Paul RH. Uterine rupture after previous cesarean delivery: maternal and fetal consequences. Am J Obstet Gynecol 1993:169:945-50

31 Bujold E, Gauthier RJ. Neonatal morbidity associated with uterine rupture: what are the risk factors? Am J Obstet Gynecol 2002;186:311-4. 